\title{
Effect of vitamin and mineral premix on the performances of growing rabbits
}

\author{
R. DESSIMONI CARREGAL and J. A. SVERZUT
}

Faculdade de Ciencias Agravias e Veterinavias "Campus " de Jaboticabal Dept. de Produçao Animal-Rod. Carlos Tonanni s/n. - Jaboticabal (Brazil)

The present work was carried out to test premix effect on the rabbit performance, from 35 to 90 days of age.

The study was made on New Zealand White rabbits weaned at 35 days of age. Weight gain, feed consumption and feed convergio rasion were recorded every week.

The experimental scheme used was a factorial $3 \times 2$ design (diet $\times$ sex) in randomized blocks with 4 replications.

The experimental diets were:

A - diet with premix.

$B$ - diet without premix.

C - removal of premix 30 days after the beginning of trial.

The results suggest that:

- Weight gain, feed conversion ratio and feed consumption were not affected by the above mentioned treatments.

- A significant effect of blocks relative to feed conversion ratio and feed consumption, was observed.

\section{Effects of dietary protein level on growth and body composition of New Zealand White rabbits}

\author{
J. OUhayoun, Danielle DELMAS \\ Laboratoire de Recherches sur l'Élevage du Lapin \\ I.N.R.A., B.P. I2, 31320 Castanet Tolosan (France)
}

This experiment was conducted to determine the influence of two protein levels ( 13.8 and I7.5 p. IOo) on weight gain, feed efficiency and carcass development of New Zealand White rabbits between 5 weeks of age ( $\mathrm{r}$ week after weaning) and slaughter $(2.4 \mathrm{~kg})$. The two diets were isoenergetic $(2600-2700 \mathrm{kcal} \mathrm{D.E} . / \mathrm{kg})$. The growth rate of the rabbits fed the low protein diet was reduced: a delay of 5 days was observed before they reached the weight of $2.4 \mathrm{~kg}$. Their feed conversion ratio and their energy efficiency were deteriorated (- Io p. IOo and $\ldots$ I3.5 p. IOo, respectively), but their protein efficiency was greatly increased ( + I9 $\mathrm{p}$. Ioo). The dressing percentage of the rabbits fed the high protein diet was higher (63.I p. Ioo vs $60.6 \mathrm{p}$. Ioo), as a consequence of the weight reduction of the following elements: digestive tract, digestive content and skin, and of the weight increase of liver. The carcass composition, as estimated by weight of interscapular and perirenal fat, weight of muscles and bones of hind leg, lipid level of muscular tissue, did not differ between treatments. These results are discussed. It is suggested that the growth rate decrease obtained by reducing the protein level of the diet involved a change in the relative development or organs and tissues. 